\title{
Occurrence of Canker Caused by Xanthomonas axonopodis pv. citri on Pummelo (Citrus maxima (Burm.) Merr.) Cultivar. Tabtimsiam in Nakhon Si Thammarat Province, Thailand and Screening Fungicides, Antibiotics and Antagonistic Bacteria against $X$. a. pv. citri in Vitro
}

\author{
Chaisit Preecha*, Wethi Wisutthiphaet, Pornsil Seephueak \\ Tropical Fruit Crop and Tree Research Center, Department of Plant Science, Faculty of Agriculture, Rajamangala University of \\ Technology Srivijaya, Nakhon Si Thammarat, Thailand \\ Email: *skpreecha@yahoo.co.uk
}

How to cite this paper: Preecha, C., Wisutthiphaet, W. and Seephueak, P. (2018) Occurrence of Canker Caused by Xanthomonas axonopodis pv. citri on Pummelo (Citrus maxima (Burm.) Merr.) Cultivar. Tabtimsiam in Nakhon Si Thammarat Province, Thailand and Screening Fungicides, Antibiotics and Antagonistic Bacteria against $X$. a. pv. citri in Vitro. Journal of Geoscience and Environment Protection, 6, 1-7.

https://doi.org/10.4236/gep.2018.63001

Received: November 4, 2017

Accepted: March 5, 2018

Published: March 8, 2018

\begin{abstract}
Pummelo (Citrus maxima (Burm.) Merr.) cultivar Tabtimsiam is the new cultivar growing in Pak Panang Basin, Nakhon Si Thammarat, southern of Thailand. It is the one of the most acceptable tropical fruit of consumers. Canker caused by Xanthomonas axonopodis pv. citri is the most seriously damage especially on fruit. This research was conducted to monitor disease severity and trialed for screening fungicides, antibiotics, and antagonistic bacteria to solve this disease at farmer orchards. The severity of canker monitoring on Tabtimsiam pummelo at 3 - 5 and 6 - 8-year age plant, on leaf was high at $11.85 \%$ and $16.37 \%$ and mature fruit was $16.15 \%$ and $17.12 \%$. The result for controlling agent screening indicated that tetracycline was the highest control of $1.12 \mathrm{~cm}$ inhibition zone. It higher than streptomycin and ampicillin of 1.02 and $0.95 \mathrm{~cm}$ inhibition zone and also distinguish higher than broad spectrum fungicide, copper hydroxide and copper oxychloride of 0.57 and $0.46 \mathrm{~cm}$ inhibition zone respectively. For antagonistic screening, only the one antagonistic bacterial, Bacillus amyloliguefacien KPS 46 expressed of secondary metabolite to inhibit $X$. a. pv. citri of $0.14 \mathrm{~cm}$ inhibition zone, while Bacillus subtilis and Paenibacillus pabuli SW01/4 did not express antagonism by produced secondary metabolite to inhibit this pathogen.
\end{abstract}




\section{Keywords}

Canker, Fungicides, Antibiotic, Antagonist

\section{Introduction}

Thailand is the land of plenty of tropical fruit crop. The most popular is rambutan, pummelo, mangosteen and durian. Pummelo is one of the most acceptable of consumers. Pummelo (Citrus maxima (Burm.) Merr.) var. Tabtimsiam is the new cultivar growing in Pak Panang Basin, Nakhon Si Thammarat, southern of Thailand. This cultivar was regarded as the premium quality both domestic and exporting market which sweet, soft red juice. Pummelo was susceptible as well as most citrus which it was severe infected by Xanthomonas axonopodis pv. citri causing agent of canker [1]. Citrus canker was the seriously damage on citrus growing area all over the world [2] [3]. Tabtimsiam Pummelo was grow in Pak Panang, Nakhon Si Thammarat, the tropical monsoon with high precipitation of $2000-2500 \mathrm{~mm} /$ year [4]. It was suitable condition of spreading of $X$. a. pv. citri from warm weather and dispersed by splashed rain and wind [5] [6] [7] [8]. The Tabtimsiam pummelo growing in this area was seriously damaged by canker disease. The fruit was infected and symptom appeared due to highly decreasing marketing quality especially in appearance performance. This research objected to study the severity of canker on leaf and mature fruit and screen fungicides, antibiotics and antagonistic bacteria against $X$. a. pv. citri.

\section{Materials and Method}

\subsection{Occurrence of Canker Disease on Tabtimsiam Pummelo}

Canker on Tabtimsiam pummelo growing at Pak Panang Basin, Nakhon Si Thammarat province was evaluated using visual estimation scale modified from Horsfall-Barratt and James [9] [10] [11]. The trees were category into 3 - 5 and 6 - 8-year age plant. Nine trees were sampled for each group to estimate canker severity. Canker disease severity on leaves and mature fruits. Disease severity score on leaf was measurement scale for visual estimation modified based on Horsfall-Barratt [9] [10] [11]. Disease severity was rated into 5 categories: 0, 5, $15,25 \%$, and $50 \%$ infection leaf area. Canker severity on fruit was evaluated using visual estimation scale modified from Domínguez et al. [12]. Fruit infection symptom was rated into 5 groups as well as leaf infected scale. Severity of canker between 3 - 5 and 6 - 8-year age plant compared analysis by Independent Two-Sample T-Test.

\subsection{Screening Screen Fungicides, Antibiotics, and Antagonistic

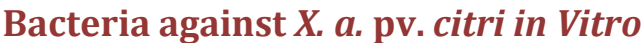

Leaf appeared of canker was collected to isolate on Nutrient Agar for $24 \mathrm{~h}$ and collected to test pathogenicity by leaf detaching technique. Young lime leaf was 
collected by cutting at the leaf stalk, clean with distill water and wrapped the leaf stalk with cotton and placed in petri dish, then dropped sterile water on cotton, $X$. a. pv. citri cultured on Nutrient Broth (NB) for $24 \mathrm{~h}$ on rotary checker was diluted to $105 \mathrm{CFU} / \mathrm{ml}$ was drop on the pricking leaf. Monitoring canker symptom was done after incubation 7 and 14 days. Pathogenic $X$. a. pv. citri isolate was picked to collect.

Antagonistic bacterial Bacillus subtilis, Bacillus amyloliguefacien KPS 46, and Paenibacillus pabuli SW01/4 was cultured in NB for $24 \mathrm{~h}$ on rotary checker. The suspension was diluted to 0.2 O.D. at $600 \mathrm{~nm}$ for using in agar diffusion test.

Fungicides and antibiotic was used at recommended dosage, including copper hydroxide $(0.57 \mathrm{mg} / \mathrm{ml})$, copper oxychloride $(0.63 \mathrm{mg} / \mathrm{ml})$, ampicillin $(0.1$ $\mathrm{mg} / \mathrm{ml})$, validamycin $(0.03 \mathrm{mg} / \mathrm{ml})$, streptomycin $(0.1 \mathrm{mg} / \mathrm{ml})$, and tetracycline $(0.1 \mathrm{mg} / \mathrm{ml})$.

Pathogen, $X$. a. pv. citri was cultured in NB for $24 \mathrm{~h}$ on rotary checker, the suspension was diluted to 0.2 O.D. at $600 \mathrm{~nm}$. Melt NA $(200 \mathrm{ml})$ was leaved until temperature decrease to 40 Celsius in water bath, then mixed with $1 \mathrm{ml} X$. a. pv. citri suspension and poured plate. After agar solidification, wells of $5-\mathrm{mm}$ diameter were cut by cork borer.

Agar diffusion technique was used to screen fungicides, antibiotics, and antagonistic bacteria against $X$. a. pv. citri. Antagonistic bacterial B. subtilis, B. amyloliguefacien KPS 46, and P. pabuli, $30 \mathrm{ul}$ of suspension prepared above was dropped on well of $X$. a. pv. citri culture prepared above. After incubation for 24 $h$, inhibition clear zone was measured to compare control efficiency.

Completely Randomized Design was statistical analysis of variance and Duncan's New Multiple Range Test was mean compare analysis.

\section{Result}

\subsection{Occurrence of Canker Disease on Tabtimsiam Pummelo}

Disease severity of canker observed on Tabtimsiam pummelo at 3 - 5 and 6 8 -year age plant showed that severity on leaf was different between 3 - 5 and 6 8 -year age plant. The severity on leaf at $3-5$ year was $11.85 \%$. It was lower than at 6 - 8 year of $16.37 \%$ (Table 1). While severity on fruit was not different between 3 - 5 and 6 - 8-year age plant which severity $16.15 \%$ and $17.12 \%$ respectively (Table 1).

\subsection{Screening Fungicides, Antibiotics, and Antagonistic Bacteria}

Fungicides, antibiotics, and antagonistic bacteria were screened in vitro to select the high potential to control $X$. a. pv. citri causing agent of canker on Tabtimsiam pummelo by agar diffusion technique. The result indicated that tetracycline was the highest control of $1.12 \mathrm{~cm}$ inhibition zone. It was higher than streptomycin and ampicillin of 1.02 and $0.95 \mathrm{~cm}$ inhibition zone and also higher than broad spectrum fungicide, copper hydroxide and copper oxychloride of 0.57 and $0.46 \mathrm{~cm}$ inhibition zone respectively (Table 2). For antagonist screening, 
Table 1. Occurrence of canker on leaves and mature fruitsof the Tabtimsiam pummelo at 3 - 5 and 6 - 8-year age plant.

\begin{tabular}{ccc}
\hline \multirow{2}{*}{ Canker disease severity and incidence } & \multicolumn{2}{c}{ Age of tree } \\
\cline { 2 - 3 } & 3 - 5-year (\%) & 6 - 8-year (\%) \\
\hline Leaf symptom & $11.85 \mathrm{~b}$ & $16.37 \mathrm{a}^{1 /}$ \\
Fruit symptom & 16.15 & 17.12 \\
\hline
\end{tabular}

${ }^{1 /}=$ Same letters in the same row indicate that values are not significantly different $(\mathrm{p}>0.05)$ with statistical analysis by Independent Two-Sample T-Test.

Table 2. Efficiency of fungicides, antibiotics and antagonistic bacteria to control Xanthomonas axonopodis pv. citri causing agent of canker on Tabtimsiam pummelo in vitro by agar diffusion.

\begin{tabular}{ccc}
\hline $\begin{array}{c}\text { Fungicides, antibiotics } \\
\text { and antagonistic bacteria }\end{array}$ & $\begin{array}{c}\text { Inhibition diameter } \\
(\mathrm{cm})\end{array}$ & $\begin{array}{c}\text { Inhibition zone } \\
(\mathrm{cm})\end{array}$ \\
\hline Copper hydroxide $0.57 \mathrm{mg} / \mathrm{ml}$ & 1.07 & $0.57 \mathrm{~d}^{1 /}$ \\
Copperoxychloride $(0.63 \mathrm{mg} / \mathrm{ml})$ & 0.96 & $0.46 \mathrm{e}$ \\
Ampicillin $(0.1 \mathrm{mg} / \mathrm{ml})$ & 1.45 & $0.95 \mathrm{c}$ \\
Validamycin $(0.03 \mathrm{mg} / \mathrm{ml})$ & 0.50 & $0.00 \mathrm{~h}$ \\
Streptomycin $(0.1 \mathrm{mg} / \mathrm{ml})$ & 1.52 & $1.02 \mathrm{~b}$ \\
Tetracycline $(0.1 \mathrm{mg} / \mathrm{ml})$ & 1.62 & $1.12 \mathrm{a}$ \\
Bacillus subtilis $\left(10^{5} \mathrm{CFU}\right)$ & 0.50 & $0.00 \mathrm{~g}$ \\
Bacillus amyloliguefacien $\mathrm{KPS} 46\left(10^{5} \mathrm{CFU}\right)$ & 0.64 & $0.14 \mathrm{f}$ \\
Paenibacillus pabuli SW01/4 $\left(10^{5} \mathrm{CFU}\right)$ & 0.50 & $0.00 \mathrm{~g}$ \\
Control & 0.50 & $0.00 \mathrm{~g}$ \\
\hline
\end{tabular}

${ }^{1 /}=$ Same letters in the same column indicate that values are not significantly different $(p>0.05)$, mean compared by DMRT.

only the one antagonistic bacterial, B. amyloliguefacien KPS 46 expressed of secondary metabolite to inhibit $X$. a. pv. citri of $0.14 \mathrm{~cm}$ inhibition zone, while $B$. subtilis and $P$. pabuli SW01/4 did not express antagonism by produced secondary metabolite to inhibit this pathogen.

\section{Discussion}

Disease severity of canker of Tabtimsiam pummelo at 3 - 5 and 6 - 8-year age plant on leaf was high at $11.85 \%$ and $16.37 \%$ and mature fruit (Table 1 ) was $16.15 \%$ and $17.12 \%$ respectively (Table 1 ). The result convince that this cultivar was susceptible to $X$. a. pv. citri and environment was enhanced more severity. which high of precipitation and high temperature. It was higher than 2000 $\mathrm{mm} /$ year [4]. This pathogen $X$. axonopodis pv. citri was favor by high temperature and humidity [5] [7] [8] [13]. More factors to initiated disease severity were growing infected seedling and epidemic of leaf miner (Phyllocnistis citrella) [14] [15] [16]. In some case, it increased canker severity up to 50\% [17]. 
Disease symptom on fruit was threatened for market acceptable both domestic and exporting. Canker scare fruit was accepted by cut fruit market only, but price dropped from $6 \mathrm{USD} /$ fruit to $3 \mathrm{USD} /$ fruit. It was not exporting. To reduce severe fruit damage copper compound was applied by farmers. It seemly was not reduce severity. Antibiotics, streptomycin and tetracycline were the highest efficient control this disease. In this screening in vitro revealed that both streptomycin and tetracycline were higher distinguishing than copper compound. It was consistent efficient control similar to previous trial [18] [19] [20] [21]. For sustainable control antagonistic bacterial $B$. amyloliguefacien KPS 46 recovered by Kasem [22] was expressed to inhibit $X$. a. pv. citri. This bacterial antagonist was tested and developed to control both bacterial diseases and fungal diseases. It has been several reports of production secondary for inhibition mode and stimulate plant by induce systemic resistance and systemic acquire resistance [23] [24] [25]. However, both antibiotic and antagonist should be test in farmer orchard before transfer to the farmers in this case.

\section{References}

[1] Brugnara, E.C., Theodoro, G.F., Nesi1, C.N., Verona, L.A.F. and Maringoni, A.C. (2012) Damage Caused by Citrus Canker on Valencia Sweet Orange Yield. IDESIA (Chile), 30, 109-113. https://doi.org/10.4067/S0718-34292012000100013

[2] Gottwald, T.R., Graham, J.H. and Schubert, T.S. (2002) Citrus Canker: The Pathogen and Its Impact. Online. Plant Health Progress. https://www.plantmanagementnetwork.org/pub/php/review/citruscanker/

[3] Gottwald, T.R., Hughes, G., Graham, J.H., Sun, X. and Riley, T. (2001) The Citrus Canker Epidemic in Florida-The Scientific Basis of Regulatory/Eradication Policy for an Invasive Plant Pathogen. Phytopathol, 91, 30-34. https://doi.org/10.1094/PHYTO.2001.91.1.30c

[4] Meteorological Department, Ministry of Information and Communication Technology (2016) Statistics of Rainfall at Meteorology Station, Nakhon Si Thammarat: 2003-2015. http://service.nso.go.th/nso/web/statseries/statseries27.html

[5] Bock, C.H., Parker, P.E. and Gottwald, T.R. (2005) Effect of Simulated Wind-Driven Rain on Duration and Distance of Dispersal of Xanthomonas axonopodis pv. citri from Canker Infected Citrus Trees. Plant Dis, 89, 71-80. https://doi.org/10.1094/PD-89-0071

[6] Das, A.K. (2003) Citrus Canker-A Review. J. Appl. Hort., 5, 52-60.

[7] Gottwald, T.R. and Irey, M. (2007) Post-Hurricane Analysis of Citrus Canker II: Predictive Model Estimation of Disease Spread and Area Potentially Impacted by Various Eradication Protocols Following Catastrophic Weather Events. Online. Plant Health Progress. http://www.apsnet.org/publications/apsnetfeatures/Pages/CitrusCankerII.aspx

[8] Khan, M.A. and Abid, M. (2007) Effect of Environmental Conditions on Citrus Canker Disease Development. Pak. J. Phytopathol, 9, 139-144.

[9] Bock, C.H., Gottwald, T.R., Parker, P.E., Cook, A.Z., Ferrandino, F., Parnell, S. and van den Bosch, F. (2009) The Horsfall-Barratt Scale and Severity Estimates of Citrus Canker. Eur J Plant Pathol, 125, 23-38. https://doi.org/10.1007/s10658-009-9455-x

[10] James, W.C. (1971) A Manual Assessment Keys for Plant Diseases. Canada Depart- 
ment of Agriculture Publication Inc.

[11] Schneider, S.J., Da Graca, J.V., Skaria, M., Little, C.R., Setamou, M. and Kunta, M. (2013) A Visual Rating Scale for Quantifying the Severity of Greasy Spot Disease on Grapefruit Leaves. Int J Fruit Sci, 13, 459-465. https://doi.org/10.1080/15538362.2013.789273

[12] Domínguez, E.G., Martins, R.B., Del Ponte, E.M., Michereff, S.J., García-Jiménez, J. and Armengo, J. (2014) Development and Validation of a Standard Area Diagram Set to Aid Assessment of Severity of Loquat Scab on Fruit. Eur J Plant Pathol, 139, 413-422.

[13] Pruvost, O., Boher, B., Brocherieus, C., Nicole, M. and Chiroleu, F. (2002) Survival of Xanthomonas axonopodis pv. citri in Leaflesions under Tropical Environmental Conditions and Simulated Splash Dispersal of Inoculum. Phytopath, 92, 336-346. https://doi.org/10.1094/PHYTO.2002.92.4.336

[14] Chagas, M.C.M., Para, J.R.P., Namekata, T., Hartung, J.S. and Yamamoto, A.P.T. (2001) Phyllocnistis citrella Stainton (Lepidoptera: Gracillariidae) and Its Relationship with the Citrus Canker Bacterium Xanthomonas axonopodis pv. citri in Brazil. Neotropical Entomol, 30, 55-59. https://doi.org/10.1590/S1519-566X2001000100009

[15] Gottwald, T.R., Graham, J.H. and Schubert, T.S. (1997) An Epidemiological Analysis of the Spread of Citrus Canker in Urban Miami, Florida, and Synergistic Interaction with the Asian Citrus Leaf Miner. Fruits, 52, 383-390.

[16] Hall, D.G., Gottwald, T.R. and Bock, C.H. (2010) Exacerbation of Canker by Citrus Leaf Miner Phyllocnistis citrella in Florida. Fla. Entomo, 93, 558-565. https://doi.org/10.1653/024.093.0413

[17] Sohi, G.S. and Sandhu, M.S. (1968) Relationship between Citrus Leafminer (Phyllocnistis citrella Stainton) Injury and Citrus Canker (Xanthomonas citri (Hasse) Dowson) Incidence on Citrus Leaves. JRes Punjab Agric Univ, 5, 66-69.

[18] Badiger, N., Yenjerappa, S.T., Naik, M.N., Patil, M.B. and Patil, M.G. (2016) Evaluation of Antibiotics, Antibacterial Chemicals and Bio-Agents against Citrus Canker Caused by Xanthomonas axonopodis pv. Int J Plant Prot., 9, 566-569. https://doi.org/10.15740/HAS/IJPP/9.2/566-569

[19] Graham, J.H., Gottwald, T.R. and Leite, R.P. (2006) Prospects for Control of Citrus Canker with Novel Chemical Compounds. Proc. Flo. State Hort. Soc., 119, 82-88.

[20] Sahii, S.T., Ghazanf, M.U., Afzal, M., Rashed, A. and Habib, A. (2007) Incidence of Citrus Canker Disease Caused by Xanthomonas campestris pv. citri (Hasse) Dows on Kinnow (Citrus reticulate) and Its Chemotherapy. Pak. J. Bot., 39, 1319-1327.

[21] Thirumalesh, B.V., Thippeswamy, B. and Krishnappa, M. (2016) In Vitro Evaluation of Chemical Formulates on Xanthomonas axonopodis pv. punicae. Int. J. Curr. Microbiol. App.Sci., 5, 443-448. https://doi.org/10.20546/ijcmas.2016.503.051

[22] Kasem, S. (2002) Identification and Characterization of Antagonistic Bacteria from Soy Bean Phyllospheres and Rhizosphere Soil to Control Soybean Bacterial Pustule. M.Sc. Thesis. Kasetsart University, Bangkok, Thailand.

[23] Prathuangwong, S., Preecha, C., Kasem, S.S., Thowthampitak, J. and Athinuwat, D. (2005) Induced Systemic Resistance and Plant Growth Promoting Elicited by Biocontrol Bacteria in the Commercial Production of Vegetable Soybean. Proc. of the 7 th Nat Plant Prot Ann Con, 2nd-4th November 2005, Chiang Mai, Thailand.

[24] Prathuangwong, S., Preecha, C., Kasem, S., Thowthampitak, J. and Athinuwat, D. (2005) Integrating Paenibacilluspabuli SW01/4 and Bacillus amyloliquefaciens KPS46 to Control Soybean Bacterial Pustule. Proc. of the IntSoc for Southeast Asian 
Agr Sci (Scientific Meeting), 13th December 2005. Hanoi Agricultural University (HAU), Hanoi.

[25] Prathuangwong, S., Kasem, S., Thowthampitak, J. and Athinuwat, D. (2004) Multiple Plant Response to Bacterial Mediated Protection Against Various Disease. J. of ISSAAS, 11, 79-87. 